Article

\title{
Can Hairy Vetch Cover Crop Affects Arsenic Accumulation in Vegetable Crops?
}

\author{
Roberto Mancinelli ${ }^{1, *} \mathbb{C}$, Emanuele Radicetti ${ }^{1, *} \mathbb{C}$, Rosario Muleo ${ }^{1}$, Sara Marinari ${ }^{2} \mathbb{C}$, \\ Ilenia Bravo ${ }^{3}$ and Patrizia Papetti ${ }^{3}$ \\ 1 Department of Agricultural and Forestry Sciences (DAFNE), University of Tuscia, \\ Via S. Camillo De Lellis snc, 01100 Viterbo, Italy; muleo@unitus.it \\ 2 Department for Innovation in Biological, Agro-Food and Forest System (DIBAF), University of Tuscia, \\ Via San Camillo de Lellis snc., 01100 Viterbo, Italy; Marinari@unitus.it \\ 3 Department of Economics and Law, Territorial and Products Analysis Laboratory (LAMeT), \\ University of Cassino and Southern Lazio, Via Sant'Angelo, Località Folcara, Cassino 03043, Italy; \\ ilenia.bravo@libero.it (I.B.); papetti@unicas.it (P.P.) \\ * Correspondence: mancinel@unitus.it (R.M.); radicetti@unitus.it (E.R.); \\ Tel.: +39-0761-357556 (R.M.); +39-0761-357556 (E.R.)
}

Received: 11 April 2019; Accepted: 27 April 2019; Published: 29 April 2019

\begin{abstract}
Agricultural practices greatly influence the bioavailability of heavy metals. Arsenic (As) is a heavy metal identified as a concern due to its potential impact on human health. Two-year field experiments were performed to evaluate the effect of cropping system on As accumulation in tomato, sweet pepper and zucchini. The treatments were: (i) conventional system based on common practices of the area; and (ii) alternative systems based on cultivation of hairy vetch (Vicia villosa Roth.) in no-tillage before vegetable crops. Randomized block design with three replications was adopted. Soil and plant samples (fruits, leaves, stems and roots) were collected at crop harvesting. Plant samples were weighed and analyzed to evaluate As content. Soil chemical analyses were performed to evaluate the total organic carbon and nitrogen content. The As accumulation observed in plant samples of tomato, sweet pepper and zucchini resulted always low in the alternative system, except in fruits where As accumulation was similar between the systems. The increase of soil organic matter observed in alternative system probably caused a reduction of As accumulation into crop tissues. Therefore, hairy vetch cultivation in no-tillage could be a suitable strategy to reduce the As uptake of vegetable crops in geogenic contaminated soils.
\end{abstract}

Keywords: arsenic accumulation; soil organic matter; cover cropping; vegetable crops

\section{Introduction}

Soil contamination by heavy metals represents an increasing problem since human activities and/or natural processes may strongly affect their transferring in the foods and groundwater [1]. Among the heavy metal, arsenic (As) is identified as a concern due to its potential impact on the environment and human health. Arsenic naturally occurs in the earth surface (on average $1.5-2.0 \mathrm{mg} \mathrm{kg}^{-1}$ ). However, as observed in many areas around the world the As concentration in soil greatly varied among the areas reaching high concentration (above $50.0 \mathrm{mg} \mathrm{kg}^{-1}$ ) in soil and water [2]. Consequently, As could be easily assimilated by plants and animals that are used for human consumption [3]. Several researches reported that As is one of the few metal elements that raises concerns of higher concentration in food chain $[4,5]$. It is well known that high As concentration in the soil produce plants with increased As content, even if the distribution of As in the plants greatly varies among the different plant organs generally showing lower values in seeds and fruits compared to leaves, stems and roots [2]. Low 
concentration of As in plant tissue does not determine specific metabolic reactions, while its high concentrations could interfere with metabolic processes inhibiting the plant growth and sometimes leading to plant death [6]. The accumulation of available soil As by plants depends on many factors, such as soil concentration, soil chemical-physical properties, presence of other ions in soil and plant species [7]. It is well-known that the applied agronomical practices in the cropping systems determine relatively immediate effects on soil organic matter (SOM) that may form complexes with elements, like As, and control its mobility and availability in soils [8]. However, under acidic soil conditions, such as in volcanic soil, SOM may compete with As for the same adsorption sites resulting in the release of As to soil solution [9]. Therefore, the knowledge on As uptake by plants and its effects on plant growth, nutrition and fruit yield represent a key-factor to understand the behavior of As in the soil-plant system [7].

Sustainable agriculture methods are considered a whole of agronomic techniques applied for producing healthy food [10-13]. Specific agronomic techniques applied in sustainable agriculture, such as the adoption of cover crops, organic fertilizers, soil tillage methods, and supplementary irrigation methods, can contribute to improve soil organic matter and soil fertility, with an increase of crop productivity and yield stability [13]. The integration of cover crops into cropping systems is considered a sustainable agricultural practice that provide several agro-ecological services in terms of soil erosion control [14], recycling of unused soil nutrients and fixing of atmospheric nitrogen [15,16], soil organic matter [17], improved soil structure [14], pests management [14,18-20] and crop productivity [21-23].

In the Mediterranean environment, cover crops have been recommended to replace bare fallow during the winter season and killed in spring just before cultivation of summer vegetable crops [24]. Hairy vetch is a legume species profitably used as winter cover crops in the mild and wet period of central Italy, which produces a large amount of biomass characterized by high $\mathrm{N}$ content and low $\mathrm{C}: \mathrm{N}$ ratio [25]. Moreover, the aboveground biomass of hairy vetch is easy to manage in conservation agriculture practice as organic dead mulch in order to prevent weed establishment [26] and reduce external inputs $[15,25]$. To date, very few studies investigated the effect of sustainable agriculture methods on the behavior of As in naturally contaminated soils. The question still needs to be addressed as to whether some specific agronomic techniques applied in sustainable agriculture could affect the accumulation of As by specific vegetable crop species. This study hypothesized that the hairy vetch biomass managed under conservation tillage practice as organic dead mulch could reduce the As uptake and accumulation in summer vegetable crops. The main aims of this study were: (i) to establish whether hairy vetch and its residues left on the soil surface as organic dead mulch affect the soil organic matter in a naturally As contaminated area; (ii) to verify whether the agronomic techniques and soil organic matter affect the As accumulation into tomato, sweet pepper and zucchini grown on geogenic contaminated soils; and (iii) to understand how the adsorbed As is translocated to the plant tissues.

\section{Materials and Methods}

\subsection{Study Area and Soil Characteristics}

The study was carried out in 2011/2012 and 2012/2013 growing seasons in a cover crop - summer vegetable sequences performed in the experimental fields of the University of Tuscia (Viterbo, Lat. $45^{\circ} 25^{\prime} \mathrm{N}$, Long. $12^{\circ} 04^{\prime} \mathrm{E}$, Alt. $310 \mathrm{~m}$ a.s.l.). The experimental area is located in central Italy characterized by soil of volcanic origin with high As concentrations related to the deep-rising fluids of the active geothermal systems [2]. The soil of the experimental site is classified as a Typic Xerofluvent [27], with $63 \%$ sand, $22 \%$ silt, $15 \%$ clay in the $0-25 \mathrm{~cm}$ depth of soil horizon and considered as sand-loam based on USDA classification of the particle size distribution analysis. The total organic $\mathrm{C}$ and $\mathrm{N}$ content was on average $1.07 \%$ and $0.12 \%$, respectively, so that the $\mathrm{C}: \mathrm{N}$ ratio 9.2 , while $\mathrm{pH}$ of 7.1 . Soil chemical and physical analyses were carried out for twelve samples collected from the experimental fields (four soil samples in each block) before starting the field experiment in September, in order to verify the field homogeneity. The soil properties did not differ within the three blocks. The study area is characterized 
by typical Mediterranean climate with cold and wet winters, especially in January and February, and hot and dry summer, especially in July and August. The annual rainfall amount is approximately $750 \mathrm{~mm}$, which is mainly distributed from September to May.

\subsection{Experimental Design and Field Description}

Field trials were carried out in two adjacent fields of the same experimental site, which was previously cropped with barley (Hordeum vulgare L.). The experimental treatments consisted in two winter soil management systems: (i) cultivation of hairy vetch (Vicia villosa Roth. var. Villana,) converted in organic mulch in spring after its termination (hereafter denominated HV), and (ii) conventional soil management (bare soil, hereafter denominated C). The present study focuses on the growth period of three different summer vegetable crops (tomato, sweet pepper and zucchini) cultivated after winter soil management. The treatments were arranged in a randomized block design with three replications, with the plot size of $240 \mathrm{~m}^{2}(24 \mathrm{~m} \times 10 \mathrm{~m})$ for the winter soil management which were divided in plot of $80 \mathrm{~m}^{2}(8 \mathrm{~m} \times 10 \mathrm{~m})$ for the cultivation of the summer vegetable crops. The plots in the experimental field were large enough to carry out all farming operations with agricultural machinery.

In September, all plots were ploughed at a 30-cm depth, fertilized with $46 \mathrm{~kg}_{\text {of }} \mathrm{P} \mathrm{ha}{ }^{-1}$ as a triple superphosphate and then harrowed at $10 \mathrm{~cm}$ depth in order to prepare the seed bed for hairy vetch sowing. Hairy vetch was sown on 26 September 2011 and 30 September 2012, respectively, at seed rates of $60 \mathrm{~kg} \mathrm{ha}^{-1}[15,16]$. In the conventional system, the soil was managed as described for hairy vetch treatments and was kept bare and weed-free throughout the winter season until to the termination of hairy vetch by chemical means (glyphosate at the concentration of $480 \mathrm{~g} \mathrm{l}^{-1}$ applied two times when the weed seedlings started to emerge at the suggested rate of $1.51 \mathrm{ha}^{-1}$ ). On 8 May 2012 and 14 May 2013 , the aboveground biomass of hairy vetch was mechanically mowed by using a hay-conditioner farm machine, which cut the biomass to a width of $180 \mathrm{~cm}$ and arranged its residues in mulch strips about $80 \mathrm{~cm}$ wide and $100 \mathrm{~cm}$ apart [28]. In the conventional treatment, the transplanting bed was prepared with plough and rotary harrow at the same time of hairy vetch termination. On 18 May 2012 and 27 May 2013, the vegetable crops [tomato (Lycopersicon esculentum Mill.-cv Ronco), sweet pepper (Capsicum annuum L.-cv. Cleor) and zucchini (Cucurbita pepo L.-cv. Primula)] were hand-transplanted in paired rows at $40 \mathrm{~cm}$ between one to another and $140 \mathrm{~cm}$ between the paired rows at a density of 3 plants $\mathrm{m}^{-2}$. The same spatial arrangement was used for all vegetable crops adopted in this study. In hairy vetch mulch, vegetable seedlings were transplanted into the mulch layer with minimal disturbance of the mulch and carefully surrounded by hairy vetch residues with a minimum of $20 \mathrm{~cm}$ wide. The same method and plant density were applied in conventional system. Vegetable crops were irrigated by using drip-irrigation tape installed over the mulch layer in hairy vetch treatments and on soil surface in the conventional system, near the vegetable seedlings $5 \mathrm{~cm}$ distance from plant rows. The amount of water input applied was uniformly distributed in order to reintegrate the maximum evapo-transpiration estimated by a class A evaporimeter and adjusted by crop coefficients. The weeds were controlled whenever required by means of a rotary hoe between the paired rows and by hand inside the paired rows. The tomato was harvested on 20 August 2013, while the sweet pepper and zucchini were manually harvested in three times during August by hand. The daily minimum and maximum temperatures and the rainfall during the study period were collected by the meteorological station close to site (Figure 1). 


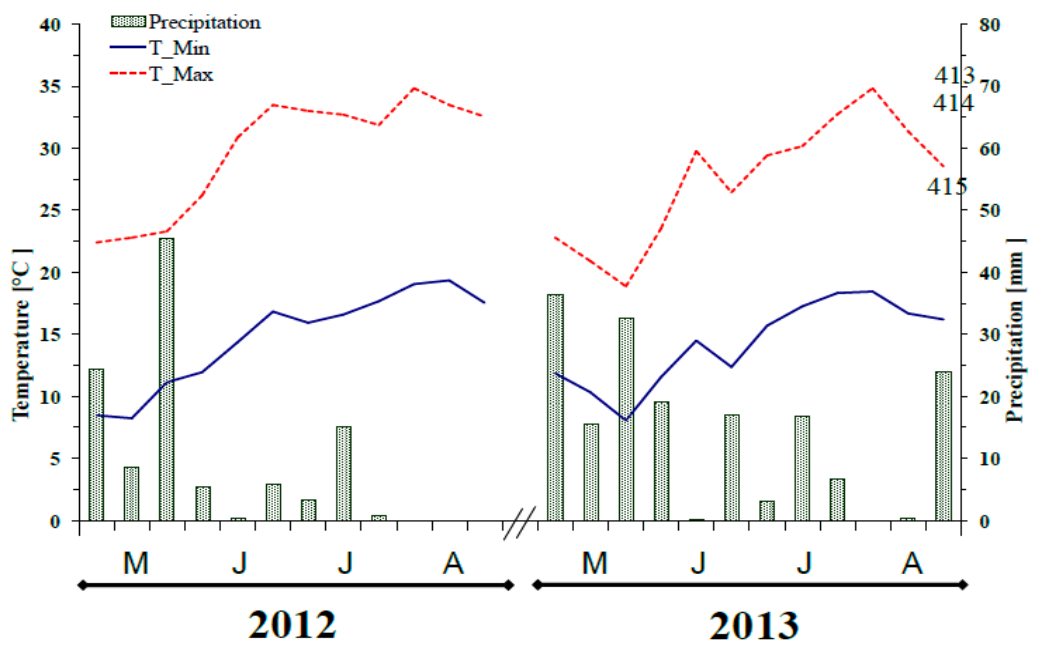

Figure 1. Weather data at 10-day intervals [maximum (-) and minimum (-) temperatures $\left({ }^{\circ} \mathrm{C}\right)$, and rainfall $(\mathrm{mm})]$ at the experimental site throughout the growing period of summer vegetable crops in 2012 and 2013.

\subsection{Sampling and Analysis of Soil, Hairy Vetch and Vegetable Crops}

In both growing seasons, the hairy vetch aboveground biomass was collected in a sampling area of $1 \mathrm{~m}^{-2}$ in the central area of each plot just before its mechanical termination. The collected sub-samples were dried at $70{ }^{\circ} \mathrm{C}$ until constant weight in order to determine their dry weight. Dried sub-samples of hairy vetch biomass were homogenized using a mill for biomass, then nitrogen $(\mathrm{N})$ and carbon (C) content were measured with an elemental analyzer (Thermo Soil NC-Flash EA1112, Lakewood, NJ, USA). The remaining samples of fresh aboveground biomass of hairy vetch were filled in the nylon bags in order to estimate the reduction of biomass, $\mathrm{N}$ and $\mathrm{C}$ remained at the harvesting of vegetable crop. The nylon bags filled with fresh hairy vetch aboveground biomass were placed across the soil surface in the centre of each plot between the paired rows of the vegetable crops using the same methodology adopted by Radicetti et al. [16]. At the final harvesting of each summer vegetable crops, the nylon bags were collected and the remained biomass was carefully separated from soil and dried at $60{ }^{\circ} \mathrm{C}$ until constant weight. The dried samples were weighed and grounded for the analysis of $\mathrm{N}$ and C concentration by using an elemental analyzer (Thermo Soil NC - Flash EA1112, Lakewood, NJ, USA).

In both growing seasons, at the final harvesting of all vegetable crops, sampling of soil and vegetable crops were performed. Ten soil samples in the central part of plot were collected at $0-30 \mathrm{~cm}$ depth and mixed together to obtain a uniform sample, for a total of 18 soil sample (6 samples for each crop). The soil samples were air-dried, sieved $(<2 \mathrm{~mm})$ and then kept at $4{ }^{\circ} \mathrm{C}$. Before the soil biochemical analyses, the moisture was adjusted to $60 \%$ of their water holding capacity and soils were re-conditioned for 5 days. The total amount of microbial biomass $\mathrm{C}$ ( $\mathrm{Cmic}$ ) and $\mathrm{N}$ (Nmic) were analyzed using the fumigation extraction (FE) method [29]. Total organic carbon (TOC) and nitrogen (TON) contents of the soil were determined using an elemental analyzer (Thermo Soil NC-Flash EA1112, Lakewood, NJ, USA).

The fruit yield and aboveground biomass of the vegetable crops were sampled in $2 \mathrm{~m}^{2}$ of a central area of each plot at crop physiological maturity. The samples were dried at $70{ }^{\circ} \mathrm{C}$ until constant weight in order to determine their dry weight, $\mathrm{C}$ and $\mathrm{N}$ content.

The As analysis of the vegetable crop biomass, separated in fruits, stems, leaves and roots, was carried out using $0.2-0.3 \mathrm{~g}$ of samples mineralized through a wet digestion process, in presence of a mixture of $3 \mathrm{~mL}$ of nitric acid $\left(\mathrm{HNO}_{3} 65 \% \mathrm{RS}\right)$ and $0.5 \mathrm{~mL}$ of a solution of hydrogen peroxide $\left(\mathrm{H}_{2} \mathrm{O}_{2} 40 \% \mathrm{~m} / \mathrm{V}\right.$ in purely stabilized water) supplied by Carlo Erba Reagents. After the acid digestion, ultrapure distilled water HIGH PURITY $18 \mathrm{M} \Omega \mathrm{cm}^{-1} 25 \mathrm{C}$ was used for the recovery of the samples, the mixture was brought to a final volume of $10 \mathrm{~mL}$ [30]. The presence of As was determined by atomic 
absorption spectrophotometer AA-600 with hydride generation FIAS-100 (Perkin Elmer, Waltham, MA, USA), with the instrument detection limit on the GFAA of $0.2 \mathrm{ppb}$. The calibration was made using appropriate dilutions of stock solution of As at $1.000 \pm 0.002 \mathrm{~g} / \mathrm{L}$ in $2 \% \mathrm{HNO}_{3}$ (CPAchem), and to ensure the reproducibility and the accuracy of the method, the same analyses were conducted on standard reference material, NIST 1570a (trace element in spinach leaves, Sigma Aldrich) with a mean recovery of about $95 \pm 1 \%$. In the graphite furnace, $20 \mu \mathrm{L}$ of sample was introduced and subsequently the analysis was atomized according to a specific temperature program. The As concentration was expressed in milligrams per kilo of dry weight ( $\mathrm{mg} \mathrm{kg}^{-1} \mathrm{~d}$.w.).

\subsection{Data Analysis and Statistics}

Statistical analyses were performed using JMP statistical software package version 4.0 [31]. The analysis of variance (ANOVA) was carried out for the two-year period, considering the year as repeated measure across time. The data analysis was carried out applying a randomized block design with three blocks and two years of experimentation. Data were analyzed using the ANOVA model with the treatment as fixed factor, the three blocks were included as a random factor and the year (growing season) was considered as random effect to account for the repeated measure across time [32]. Bartlett test was performed to test if data have equal variance, when necessary to homogenize the variance, the data were subjected to angular transformation before the variance analysis [33]. The data reported in the tables were back transformed. Fisher's protected least significant differences (LSD) at the 0.05 probability level $(p \leq 0.05)$ were used for comparing the main effects. Linear regressions were performed for selected variables using JMP statistical software package version 4.0.

\section{Results and Discussion}

The weather conditions measured during the growing season of summer vegetable crops, from May to August, tended to be similar in the two years (Figure 1). However, the total rainfall was slightly higher in 2013 than in 2012, 162 vs. $119 \mathrm{~mm}$, respectively, even if both growing seasons resulted drier compared to the historical data (i.e., $229 \mathrm{~mm}$ ). The average of minimum air temperatures was similar in 2012 and 2013 growing seasons $\left(14.6{ }^{\circ} \mathrm{C}\right)$, whereas high temperatures were slightly higher in 2012 than 2013, 28.8 vs. $27.5^{\circ} \mathrm{C}$, respectively (Figure 1). Hairy vetch emerged after two weeks from the sowing and grown regularly throughout the entire growing seasons until its suppression in both experimental years. At the transplanting of the summer vegetable crops, hairy vetch cover crop accumulated $564 \mathrm{~g} \mathrm{~m}^{-2}$ of dry weight (d.w.) characterized by $41.5 \%$ of carbon, $3.8 \%$ of nitrogen and a low C:N ratio (11.1, Table 1). These data are in according to those observed by Radicetti et al. [16] in a previous research in the same environmental condition. As expected at harvesting time of the summer vegetable crops, hairy vetch residues left on the soil surface as organic dead mulches rapidly decomposed until a significant reduction $(-62 \%$, Table 1$)$. At the same time the carbon and nitrogen content in the hairy vetch residues were reduced of $4 \%$ and $28 \%$, respectively, that corresponded at the quantity of $1.5 \mathrm{MgC} \mathrm{ha}^{-1}$ and $156 \mathrm{~kg} \mathrm{~N} \mathrm{ha}^{-1}$, respectively. It is known that residues of leguminous plants with low $\mathrm{C}: \mathrm{N}$ ratio rapidly decompose, although the biomass mineralization rate and nutrient release are both related on adopted agronomical practices [15] and edaphic and climatic conditions [34]. In accordance with other studies, the hairy vetch residues left as mulch on the soil surface in no-tillage conditions could be a good agronomic strategy for sustainable agriculture, because the slow biomass mineralization enhances the nitrogen efficiency use of the vegetable crops [15]. Furthermore, the results showed an increase of $0.3 \%$ and $0.03 \%$ of TOC and TON, respectively, compared to the conventional system (Table 2). 
Table 1. Characteristics of hairy vetch biomass (aboveground production, carbon content, nitrogen content, $\mathrm{C}: \mathrm{N}$ ratio, carbon and nitrogen) at transplanting and harvesting of the summer vegetable crops.

\begin{tabular}{ccccc}
\hline Hairy Vetch & \multicolumn{2}{c}{ Transplanting } & \multicolumn{2}{c}{ Harvesting } \\
\hline Aboveground biomass $\left(\mathrm{g} \mathrm{m}^{-2} \mathrm{~d} . \mathrm{w}.\right)$ & $564 \mathrm{a}$ & $(45)$ & $214 \mathrm{~b}$ & $(28)$ \\
Carbon in biomass (\%) & $41.5 \mathrm{a}$ & $(0.22)$ & $39.8 \mathrm{~b}$ & $(1.09)$ \\
Nitrogen in biomass (\%) & $3.8 \mathrm{a}$ & $(0.20)$ & $2.7 \mathrm{~b}$ & $(0.02)$ \\
C:N in biomass & $11.1 \mathrm{~b}$ & $(0.7)$ & $14.7 \mathrm{a}$ & $(0.5)$ \\
Carbon in biomass $\left(\mathrm{kg} \mathrm{C} \mathrm{ha}^{-1}\right)$ & $2337 \mathrm{a}$ & $(176)$ & $848 \mathrm{~b}$ & $(94)$ \\
Nitrogen in biomass $\left(\mathrm{kg} \mathrm{N} \mathrm{ha}^{-1}\right)$ & $214 \mathrm{a}$ & $(26)$ & $58 \mathrm{~b}$ & $(8)$
\end{tabular}

Data are averaged among the summer vegetable crops and correspond to the 2012 and 2013 growing seasons. Values in brackets are the standard errors. Values belonging to the same parameter in row with different letters are statistically different according to LSD $(p \leq 0.05)$.

Table 2. Effect of the hairy vetch mulching on the soil TOC (total organic carbon), TON (total organic nitrogen), microbial carbon ( $\mathrm{Cmic}$ ), microbial nitrogen (Nmic) at vegetable crops harvesting.

\begin{tabular}{ccccccccc}
\hline & \multicolumn{2}{c}{ TOC (\%) } & \multicolumn{2}{c}{ TON (\%) } & \multicolumn{2}{c}{ Cmic (g Cmic g $\left.\mathbf{~ C m}^{\mathbf{1}}\right)$} & \multicolumn{2}{c}{ Nmic $\left(\mathbf{g ~ N m i c ~ g ~}^{\mathbf{- 1}}\right)$} \\
\hline Conventional & $1.521 \mathrm{~b}$ & $(0.01)$ & $0.135 \mathrm{~b}$ & $(0.01)$ & $263.33 \mathrm{~b}$ & $(11.80)$ & $111.51 \mathrm{a}$ & $(7.79)$ \\
Hairy vetch & $1.793 \mathrm{a}$ & $(0.12)$ & $0.161 \mathrm{a}$ & $(0.01)$ & $326.39 \mathrm{a}$ & $(21.15)$ & $110.19 \mathrm{a}$ & $(0.77)$ \\
\hline
\end{tabular}

Data are averaged among the summer vegetable crops and correspond to the 2012 and 2013 growing seasons. Values in brackets are the standard errors. Values belonging to the same parameter with different letters are statistically different according to LSD $(p<0.05)$.

The management of hairy vetch in conservation tillage practice in rotation with summer vegetable crops characterized by a short growing period significantly contributed to improve the soil fertility under Mediterranean environment [35]. Moreover, the inclusion of hairy vetch as a winter cover crop probably created a more intense rhizodeposition and root turnover that may have enhanced the microbial biomass (Table 3) [36]. In agreement with other studies [25,37,38], the enhanced soil fertility, due to the increased $\mathrm{C}$ and $\mathrm{N}$ content in the soil under hairy vetch treatment, induced positive response of fruit yield of the three vegetable crops production (Table 3). This positive effect determined by the hairy vetch cover crop was observed in the sweet pepper crop, which increased the fresh fruit yield of $43 \%$ compared to the conventional system, while the increasing of the fresh fruit yield was higher of $26 \%$ and $12 \%$ for tomato and zucchini, respectively, compared to the conventional system. Similarly, the other plant parameters measured (i.e., leaves, stems and roots) were always higher in hairy vetch compared to conventional treatments for all summer vegetable crops (Table 3). Therefore, the harvest index (HI) calculated on total dry biomass showed the highest values in the cropping system with hairy vetch cover crop compared to the conventional one. In particular the HI for tomato was $0.86 \mathrm{vs}$. 0.72 , for sweet pepper, 1.05 vs. 0.95 , and for zucchini 2.37 vs. 1.57 , respectively.

Table 3. Effect of hairy vetch mulching on fruit yield, leaves, stems, roots and harvest index (HI) of the summer vegetable crops.

\begin{tabular}{|c|c|c|c|c|c|c|c|c|c|c|}
\hline & \multicolumn{2}{|c|}{ Fruits Production } & \multicolumn{2}{|c|}{ Leaves } & & \multicolumn{2}{|c|}{ Stems } & Roots & \multicolumn{2}{|c|}{ HI } \\
\hline & \multicolumn{2}{|c|}{$-\cdots\left(\mathrm{g} \mathrm{m}^{-2}\right.$ of f.w. $)-\cdots$} & \multicolumn{8}{|c|}{ - } \\
\hline Tomato & & & & & & & & & & \\
\hline Conventional & $5573.9 \mathrm{~b}$ & $(152.9)$ & $176.9 \mathrm{~b}$ & $(10.4)$ & $317.0 \mathrm{~b}$ & $(7.6)$ & $55.0 \mathrm{~b}$ & $(4.8)$ & $0.72 \mathrm{~b}$ & $(0.01)$ \\
\hline Hairy vetch & 7016.7 a & $(143.0)$ & 212.6 a & $(7.6)$ & $382.2 \mathrm{a}$ & $(8.6)$ & $70.3 \mathrm{a}$ & (3.3) & $0.86 \mathrm{a}$ & $(0.03)$ \\
\hline \multicolumn{11}{|l|}{ Sweet pepper } \\
\hline Conventional & $5218.3 \mathrm{~b}$ & (1133.7) & $163.8 \mathrm{~b}$ & $(6.3)$ & $205.9 \mathrm{~b}$ & (6.3) & $48.9 \mathrm{~b}$ & (3.4) & $0.95 \mathrm{a}$ & (0.03) \\
\hline Hairy vetch & 7448.3 a & $(287.4)$ & 248.4 a & $(1.5)$ & $248.4 \mathrm{a}$ & (1.5) & $70.1 \mathrm{a}$ & (1.6) & $1.05 \mathrm{a}$ & $(0.20)$ \\
\hline \multicolumn{11}{|l|}{ Zucchini } \\
\hline Conventional & $7286.4 \mathrm{~b}$ & (183.6) & $73.2 \mathrm{~b}$ & $(5.6)$ & $92.9 \mathrm{~b}$ & (8.5) & $7.0 \mathrm{a}$ & $(0.9)$ & $1.57 \mathrm{~b}$ & $(0.04)$ \\
\hline Hairy vetch & 8147.6 a & (297.8) & $93.3 \mathrm{a}$ & $(7.1)$ & $134.0 \mathrm{a}$ & (7.1) & $9.2 \mathrm{a}$ & $(0.7)$ & $2.37 \mathrm{a}$ & $(0.07)$ \\
\hline
\end{tabular}

Data correspond to the 2012 and 2013 growing seasons. Values in brackets are the standard errors. Values belonging to the same parameter with different letters are statistically different according to LSD $(p<0.05)$. Harvest index (HI) $=($ Fruit yield $/$ Biological yield $)$. F.w. $=$ fresh weight; d.w. $=$ dry weight. 
The As accumulated into roots, stems, leaves, fruits and total biomass of tomato, sweet pepper and zucchini crops resulted always lower in the alternative cropping system with hairy vetch mulching treatment than in conventional one (Table 4). In the tomato crop, the reduction of As accumulation was $50 \%, 18 \%$ and $50 \%$ in roots, stems and leaves, respectively, even if the As content was similar in tomato fruits regardless the winter soil management (on average $0.070 \mathrm{mg} \mathrm{kg}^{-1}$ d.w., Table 4). Similarly, in the sweet pepper crop, the hairy vetch mulching system reduced the As accumulation of $37 \%, 31 \%$ and $73 \%$ in root, stem and leaf respectively, compared to the conventional one, while in the zucchini crop the reduction of As accumulation was $64 \%, 31 \%$ and $16 \%$ in root, stem and leaf respectively. According to Stazi et al. [2], crop plants grown in rich As soil accumulate it in all plant organs, even if the As accumulation tended to be higher in roots, stems and leaves compared to the fruits. In fact, averaged among all vegetable crops, the As content in fruit represent only the $4 \%$ of the total As accumulated by the whole plant (Table 4). In any case, in this study, all vegetable fruits always do not exceed the suggested thresholds recommended by the European Food Safety Authority regarding the dietary exposure, where the average value is $4.6 \mathrm{mg} \mathrm{kg}^{-1}$ for tomato, $12.0 \mathrm{mg} \mathrm{kg}^{-1}$ for pepper and $4.9 \mathrm{mg} \mathrm{kg}^{-1}$ for zucchini, respectively [39]. Although the As translocated in the vegetable fruits was similar in both systems, these results induce the assumption that the alternative cropping system based on hairy vetch cultivation under no-tillage conditions could cause a stratification of inorganic As due to its immobilization in hairy vetch biomass and soil organic matter, thus resulting in a positive effect in reducing the As accumulation in various vegetable crop tissues (Figure 2), in agreement with other studies [2,40]. In fact, the hairy vetch treatments in combination with no-tillage practice resulted to improve SOM content due to the addition of plant residues from cover crop that probably promoted the adsorption of As in the soil resulting unavailable for plant uptake. Conversely, the high As accumulation observed in the conventional management was probably due to high-soil As availability as determined by intensive agricultural inputs, such as soil tillage, which caused high mineralization rate of soil organic matter. The regressions of soil total organic carbon plotted against the As accumulated in all considered vegetable crops resulted significant for the As accumulated in the roots and in the total biomass (Figure 2), while not significant relationship was observed between the As accumulated in vegetable fruits and TOC $(p>0.05)$.
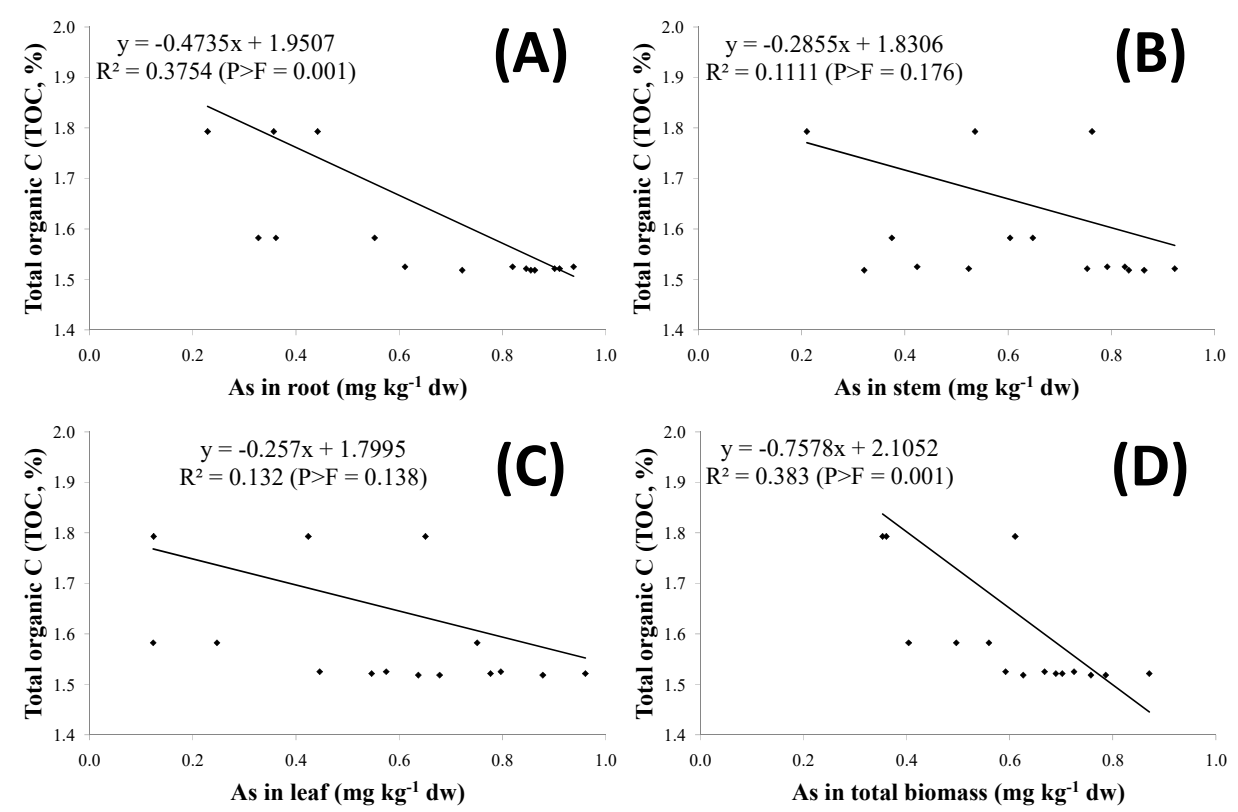

Figure 2. Relationship between total organic carbon (TOC) and As content in roots (A), stems (B), leaves (C) and total biomass (D) measured in all considered vegetable crops. Data correspond to 2012 and 2013 growing seasons. 
Table 4. Effect of the hairy vetch mulching on the As uptake in fruit, root, stem, leaves and total biomass.

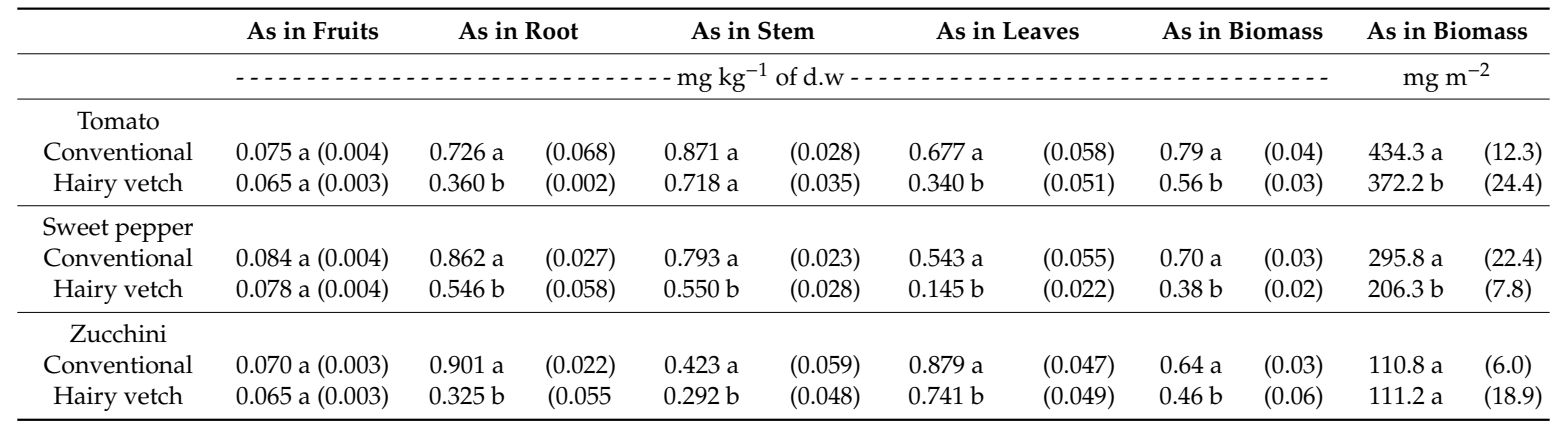

Data correspond to the 2012 and 2013 growing seasons. Values in brackets are the standard errors. Values belonging to the same parameter with different letters are statistically different according to LSD $(p<0.05)$. D.w. $=$ dry weight.

\section{Conclusions}

The adoption of an alternative cropping system based on the cultivation of hairy vetch residues in conservation tillage conditions and converted in organic dead mulch before the vegetable cultivation could be considered a sustainable agricultural practice that determine an increase of soil organic matter and yield of the following summer vegetable crops in Mediterranean environment. Furthermore, this alternative system positively affected the As depletion in the plant tissue by reducing the As content, especially in the roots, stems, leaves and in the total biomass of tomato, sweet pepper and zucchini. Although the As accumulation in the vegetable fruits was similar between the management systems, it was always lower compared to the As accumulated in the other plant tissues and represent only the $4 \%$ of the As accumulated in the whole plant. This study demonstrated that the adoption of sustainable management practice that favor the enhancement of soil organic matter could be the way to reduce the As uptake of summer vegetable crops in geogenic contaminated soils.

Author Contributions: Conceptualization, R.M. (Roberto Mancinelli) and E.R.; Methodology, R.M. (Roberto Mancinelli); Software, R.M. (Roberto Mancinelli); Validation, R.M. (Roberto Mancinelli), E.R. and R.M. (Rosario Muleo); Formal Analysis, R.M. (Roberto Mancinelli); Investigation, E.R., S.M., I.B. and P.P.; Data Curation, Roberto Mancinelli; Writing-Original Draft Preparation, R.M. (Roberto Mancinelli), E.R., R.M. (Rosario Muleo), S.M., I.B., P.P.; Writing-Review \& Editing, R.M. (Roberto Mancinelli), E.R.; Supervision, R.M. (Roberto Mancinelli); All authors contributed to writing, discussing and commenting the manuscript.

Funding: This research received no external funding and it was funded by the University of Tuscia.

Acknowledgments: The research was partially supported by MIUR (Minister for Education, University and Research, Law 232/216, Department of Excellence). The authors would like to thank Claudio Stefanoni and Fulvia Gatti for the technical support of the field experiments.

Conflicts of Interest: The authors declare no conflict of interest.

\section{References}

1. Lynch, H.N.; Greenberg, G.I; Pollock, M.C.; Lewis, A.S. A comprehensive evaluation of inorganic arsenic in food and considerations for dietary intake analyses. Sci. Total Environ. 2014, 496, 299-313. [CrossRef] [PubMed]

2. Stazi, S.R.; Mancinelli, R.; Marabottini, R.; Allevato, E.; Radicetti, E.; Campiglia, E.; Marinari, S. Influence of organic management on As bioavailability: Soil quality and tomato As uptake. Chemosphere 2018, 211, 352-359. [CrossRef]

3. Koch, I.; Dee, J.; House, K.; Sui, J.; Zhang, J.; McKnight-Whitford, A.; Reimer, K.J. Bioaccessibility and speciation of arsenic in country foods from contaminated sites in Canada. Sci. Total Environ. 2013, 449, 1-8. [CrossRef] [PubMed]

4. Green, P.G.; Li, C.; Gaudin, A.C.M.; Akbar, N.; Carrijo, D.R.; Reis, A.F.B.; Linquist, B.A.; Parikh, S.J. Impacts of variable soil drying in alternate wetting and drying rice systems on yields, grain arsenic concentration and soil moisture dynamics. Field Crop. Res. 2018, 222, 101-110. 
5. Shaw, R.K.; Maddaloni, M.; Deeb, M.; Cheng, Z.; Groffman, P.M.; Paltseva, A. Accumulation of arsenic and lead in garden-grown vegetables: Factors and mitigation strategies. Sci. Total Environ. 2018, 640-641, 273-283.

6. Marin, A.R.; Masscheleyn, P.H.; Patrick, W.H. The influence of chemical form and concentration of arsenic on rice growth and tissue arsenic concentration. Plant Soil 1992, 139, 175-183. [CrossRef]

7. Burló, F.; Guijarro, I.; Carbonell-Barrachina, A.A.; Valero, D.; Martínez-Sánchez, F. Arsenic species: Effects on and accumulation by tomato plants. J. Agric. Food Chem. 1999, 47, 1247-1253. [CrossRef]

8. Madeira, A.C.; de Varennes, A.; Abreu, M.M.; Esteves, C.; Magalhães, M.C.F. Tomato and parsley growth, arsenic uptake and translocation in a contaminated amended soil. J. Geochem. Explor. 2012, 123, 114-121. [CrossRef]

9. Wang, S.; Mulligan, C.N. Natural attenuation processes for remediation of arsenic contaminated soils and groundwater. J. Hazard. Mater. 2006, 138, 459-470. [CrossRef]

10. Tittonell, P. Ecological intensification of agriculture-sustainable by nature. Curr. Opin. Environ. Sustain. 2014, 8, 53-61. [CrossRef]

11. Alberola, C.; Lichtfouse, E.; Navarrete, M.; Debaeke, P.; Souchère, V. Agronomy for sustainable development. Italy J. Agron. 2008, 3, 77-78.

12. Hobbs, P.R. Conservation agriculture: What is it and why is it important for future sustainable food production? J. Agric. Sci. 2007, 145, 127-137. [CrossRef]

13. Komatsuzaki, M.; Ohta, H. Soil management practices for sustainable agro-ecosystems. Sustain. Sci. 2007, 2, 103-120. [CrossRef]

14. Hartwig, N.L.; Ammon, H.U. Cover crops and living mulches. Weed Sci. 2002, 50, 688-699. [CrossRef]

15. Radicetti, E.; Campiglia, E.; Marucci, A.; Mancinelli, R. How winter cover crops and tillage intensities affect nitrogen availability in eggplant. Nutr. Cycl. Agroecosyst. 2017, 108, 177-194. [CrossRef]

16. Radicetti, E.; Mancinelli, R.; Moscetti, R.; Campiglia, E. Management of winter cover crop residues under different tillage conditions affects nitrogen utilization efficiency and yield of eggplant (Solanum melanogena L.) in Mediterranean environment. Soil Tillage Res. 2016, 155, 329-338. [CrossRef]

17. Snapp, S.; Swinton, S.; Labarta, R. Evaluating cover crops for benefits, costs and performance within cropping system niches. Agron. J. 2005, 322-332.

18. Schipanski, M.E.; Barbercheck, M.; Douglas, M.R.; Finney, D.M.; Haider, K.; Kaye, J.P.; Kemanian, A.R.; Mortensen, D.A.; Ryan, M.R.; Tooker, J.; et al. A framework for evaluating ecosystem services provided by cover crops in agroecosystems. Agric. Syst. 2014, 125, 12-22. [CrossRef]

19. Robačer, M.; Canali, S.; Kristensen, H.L.; Bavec, F.; Mlakar, S.G.; Jakop, M.; Bavec, M. Cover crops in organic field vegetable production. Sci. Hortic. 2016, 208, 104-110. [CrossRef]

20. Radicetti, E.; Mancinelli, R.; Campiglia, E. Impact of managing cover crop residues on the floristic composition and species diversity of the weed community of pepper crop (Capsicum annuum L.). Crop Prot. 2013, 44, 109-119. [CrossRef]

21. Kramberger, B.; Gselman, A.; Janzekovic, M.; Kaligaric, M.; Bracko, B. Effects of cover crops on soil mineral nitrogen and on the yield and nitrogen content of maize. Eur. J. Agron. 2009, 31, 103-109. [CrossRef]

22. Mafakheri, S.; Ardakani, M.R.; Meighani, F.; Mirhadi, M.J.; Vazan, S. Rye cover crop management affects weeds and yield of corn (Zea mays L.). Not. Bot. Hort. Agrobot. 2010, 38, 117-123.

23. Sainju, U.M.; Whitehead, W.F.; Singh, B.P.; Wang, S. Tillage, cover crops, and nitrogen fertilization effects on soil nitrogen and cotton and sorghum yields. Eur. J. Agron. 2006, 25, 372-382. [CrossRef]

24. Radicetti, E.; Osipitan, O.A.; Reza, A.; Langeroodi, S.; Marinari, S.; Mancinelli, R. $\mathrm{CO}_{2}$ Flux and C Balance due to the Replacement of Bare Soil with Agro-Ecological Service Crops in Mediterranean Environment. Agriculture 2019, 9, 71. [CrossRef]

25. Langeroodi, A.S.; Radicetti, E.; Campiglia, E. How cover crop residue management and herbicide rate affect weed management and yield of tomato (Solanum lycopersicon L.) crop. Renew. Agric. Food Syst. 2018, 1-9. [CrossRef]

26. Campiglia, E.; Radicetti, E.; Mancinelli, R. Cover crops and mulches influence weed management and weed flora composition in strip-tilled tomato (Solanum lycopersicum). Weed Res. 2015, 55, 416-425. [CrossRef]

27. Soil Survey Staff Soil Survey Geographic (SSURGO) Database for [U.S.]. Available online: http://soildatamart. nrcs.usda.gov (accessed on 11 April 2019). 
28. Campiglia, E.; Caporali, F.; Radicetti, E.; Mancinelli, R. Hairy vetch (Vicia villosa Roth.) cover crop residue management for improving weed control and yield in no-tillage tomato (Lycopersicon esculentum Mill.) production. Eur. J. Agron. 2010, 33, 94-102. [CrossRef]

29. Vance, E.D.; Brookes, P.C.; Jenkinson, D.S. An extraction method for measuring soil microbial biomass C. Soil Biol. Biochem. 1987, 19, 703-707. [CrossRef]

30. Papetti, P.; Rossi, G. Heavy metals in the fishery products of low Lazio and the use of metallothionein as a biomarker of contamination. Environ. Monit. Assess. 2009, 159, 589-598. [CrossRef]

31. Littell, R.C.; Milliken, G.A.; Stroup, W.W.; Wolfinger, R.D. SAS System for Mixed Models; SAS Institute: Cary, NC, USA, 1996; ISBN 1555447791.

32. Cody, R.P.; Smith, J.K. Applied Statistics and the SAS Programming Language, 4th ed.; Prentice Hall: Upper Saddle River, NJ, USA, 1997.

33. Gomez, K.A.; Gomez, A.A. Statistical Procedures for Agricultural Research; John Wiley \& Sons: Hoboken, NJ, USA, 1984.

34. Agehara, S.; Warncke, D.D. Soil Moisture and Temperature Effects on Nitrogen Release from Organic Nitrogen Sources. Soil Sci. Soc. Am. J. 2005, 69, 1844-1855. [CrossRef]

35. Steenwerth, K.; Belina, K.M. Cover crops enhance soil organic matter, carbon dynamics and microbiological function in a vineyard agroecosystem. Appl. Soil Ecol. 2008, 40, 359-369. [CrossRef]

36. Kong, A.Y.Y.; Six, J. Microbial community assimilation of cover crop rhizodeposition within soil microenvironments in alternative and conventional cropping systems. Plant Soil 2012, 356, 315-330. [CrossRef]

37. Radicetti, E.; Massantini, R.; Campiglia, E.; Mancinelli, R.; Ferri, S.; Moscetti, R. Yield and quality of eggplant (Solanum melongena L.) as affected by cover crop species and residue management. Sci. Hortic. 2016, 204, 161-171. [CrossRef]

38. Campiglia, E.; Radicetti, E.; Brunetti, P.; Mancinelli, R. Do cover crop species and residue management play a leading role in pepper productivity? Sci. Hortic. 2014, 166, 97-104. [CrossRef]

39. European Food Safety Authority. Scientific report of EFSA-Dietary exposure to inorganic arsenic in the Europe population. EFSA J. 2014, 12, 3597.

40. De Oliveira, L.M.; Suchismita, D.; Gress, J.; Rathinasabapathi, B.; Chen, Y.; Ma, L.Q. Arsenic uptake by lettuce from As-contaminated soil remediated with Pteris vittata and organic amendment. Chemosphere 2017, 176, 249-254. [CrossRef] 